\title{
Somatic activating BRAF variants cause isolated lymphatic malformations
}

Authors: Kaitlyn Zenner, ${ }^{1,2}$ Dana M. Jensen, ${ }^{3}$ Victoria Dmyterko, ${ }^{3}$ Giridhar M. Shivaram, ${ }^{4}$

Candace T. Myers, ${ }^{5}$ Cate R. Paschal, ${ }^{5}$ Erin R. Rudzinski ${ }^{5}$, Minh-Hang M. Pham ${ }^{6}$, V. Chi Cheng ${ }^{6}$, Scott C. Manning ${ }^{1}$, Randall A. Bly, ${ }^{1,2}$ Sheila Ganti, ${ }^{1,2,7}$ Jonathan A. Perkins, ${ }^{1,2}$ James T.

Bennett ${ }^{2,3,8^{*}}$

\section{Affiliations:}

${ }^{1}$ Seattle Children's Hospital, Division of Pediatric Otolaryngology, Department of

Otolaryngology/Head and Neck Surgery, University of Washington, Seattle, WA, 98195, USA.

${ }^{2}$ Vascular Anomalies Program, Seattle Children's Hospital, Seattle, WA, 98105, USA.

${ }^{3}$ Center for Developmental Biology and Regenerative Medicine, Seattle Children's Research Institute, Seattle, WA, 98101, USA.

${ }^{4}$ Department of Radiology, Division of Interventional Radiology, University of Washington School of Medicine, Seattle

${ }^{5}$ Seattle Children's Hospital, Department of Laboratories, Seattle, WA 98105

${ }^{6}$ Center for Integrative Brain Research, Seattle Children's Research Institute, Seattle, WA, 98101, USA.

${ }^{7}$ Center for Clinical and Translational Research, Seattle Children's Research Institute, Seattle, WA, 98101, USA.

${ }^{6}$ Seattle Children's Hospital, Division of Genetic Medicine, Department of Pediatrics, University of Washington, Seattle, WA, 98195, USA.

${ }^{*}$ Corresponding Author: James T. Bennett, $19009^{\text {th }}$ Ave, M/S JMB 5, Seattle, WA 98101, +1 (206) 884-2324, jtbenn@uw.edu 


\section{Abstract}

Somatic activating variants in PIK3CA, the gene that encodes the $\mathrm{p} 110 \alpha$ catalytic subunit of PI3K, have been previously detected in $\sim 80 \%$ of lymphatic malformations (LM). ${ }^{1 ; 2}$ We report the presence of somatic activating variants in $B R A F$ in individuals with PIK3CA-negative LM. The BRAF substitution p.Val600Glu (c.1799T>A), one of the most common driver mutations in cancer, was detected in multiple individuals with LM. Histology revealed abnormal lymphatic channels with immunopositivity for BRAF ${ }^{\mathrm{V} 600 \mathrm{E}}$ in endothelial cells that was otherwise indistinguishable from PIK3CA positive LM. The finding that BRAF variants contribute to lowflow LMs increases the complexity of prior models associating low flow vascular malformations (LM and venous malformations) with mutations in the PI3K-AKT-MTOR and high flow vascular malformations (arteriovenous malformations) with mutations in the RAS-MAPK pathway. ${ }^{3}$ Additionally, this work highlights the importance of genetic diagnosis prior to initiating medical therapy as more studies examine therapeutics for individuals with vascular malformations. 
medRxiv preprint doi: https://doi.org/10.1101/2021.11.03.21265682; this version posted November 5, 2021. The copyright holder for this preprint (which was not certified by peer review) is the author/funder, who has granted medRxiv a license to display the preprint in perpetuity.

It is made available under a CC-BY-ND 4.0 International license .

\section{Main text}

Disorganized morphogenesis of arteries, veins, capillaries, and lymphatic vessels results in vascular malformations, a relatively common congenital malformation associated with significant morbidity. ${ }^{4}$ Vascular malformations are classified into high-flow lesions, which include arteriovenous malformations (AVMs), and low-flow lesions, which include venous malformations (VeM) and lymphatic malformations (LM). Individuals with vascular malformations typically have no family history because most are caused by post-zygotic (mosaic) activating mutations in oncogenes within the PI3K-AKT and RAS-MAPK pathways. ${ }^{1-3}$ Treatments for vascular malformations are primarily invasive and include sclerotherapy, embolization, and open surgical resection, ${ }^{4}$ but the identification of specific activating mutations in well-known oncogenic signaling pathways has led to trials examining the efficacy of targeted medical therapies. ${ }^{5-11}$

Previous work has shown that approximately $80 \%$ of isolated LM have somatic pathogenic variants in PIK3CA, ${ }^{1 ; 2 ; 12}$ the gene that encodes for the catalytic subunit of phosphatidylinositol 3-kinase (PI3K), a component of the PI3K-AKT pathway. ${ }^{13}$ PIK $3 C A$ is the only gene associated with isolated LM to date, and the vast majority ( $>90 \%)$ of LM associated pathogenic variants occur at one of three locations, referred to as "hotspots": c. $1624 \mathrm{G}>\mathrm{A}$ (p.E542K), c.1633G>A (p.E545K), and c.3140A>G (p.H1047R), all of which result in PI3K hyperactivation. ${ }^{14 ; 15}$ The fraction of DNA molecules that possess the pathogenic PIK3CA variant (referred to as the variant allele fraction or VAF) within LM tissue is typically very low $(<10 \%),{ }^{2}$ and it has been hypothesized that a fraction of LMs without a detected PIK3CA variant ("PIK3CA-negative LM") in fact do carry a PIK3CA variant that was "missed" due to low level mosaicism. It is also possible that additional genes play a role. Here, we report the identification of somatic BRAF mutations in PIK3CA-negative isolated LM as well as "missed" PIK3CA variants in PIK3CA-hotspot negative LM.

LM tissue from 106 individuals was screened for the three PIK3CA (NM_006218.4) hotspots (p.Glu542Lys, p.Glu545Lys, and p.His1047Arg) using droplet digital polymerase chain 
medRxiv preprint doi: https://doi.org/10.1101/2021.11.03.21265682; this version posted November 5, 2021. The copyright holder for this preprint (which was not certified by peer review) is the author/funder, who has granted medRxiv a license to display the preprint in perpetuity.

It is made available under a CC-BY-ND 4.0 International license .

reaction (ddPCR) assays and molecular inversion probes, as previously reported

(Supplemental Methods). ${ }^{2}$ Following this screening 22 individuals remained without a detected PIK3CA variant. Fifteen of these individuals had sufficient DNA (14 lesion-derived and 1 cyst fluid) for further testing, which was sent for high-depth targeted sequencing using a 44 gene panel, referred to as VANseq (Vascular ANomaly sequencing, see Supplemental Methods and Table S1) throughout the rest of this paper

VANseq identified variants in 6/15 individuals (Table 1). One individual (LR18-536) had a non-hotspot PIK3CA variant, c.1035T>A (p.Asn345Lys) that could not have been detected by hotspot allele-specific ddPCR screening. This variant is absent from the Genome Aggregation Database (gnomAD), is predicted to be damaging by several in silico tools, and has been previously reported in numerous individuals with cancer as well as one individual with CLOVES syndrome. ${ }^{1 ; 16 ; 17}$ Functional studies have demonstrated that this substitution results in PI3K pathway hyperactivity. ${ }^{14 ; 15}$ Although not previously reported in association with isolated LM, we interpreted this variant as being pathogenic, ${ }^{18}$ and confirmed the presence of the variant in additional samples from that individual using ddPCR. There was variation in VAF from undetectable to $1.4 \%$ within lesion samples (Table 1 ), as we have previously described. ${ }^{2}$

VANseq detected a hotspot PIK3CA variant (p.Glu545Lys) in two individuals (LR16-278 and LR16-264), who had previously screened negative for this allele by ddPCR. ${ }^{2}$ We reexamined prior data from both cases. LR16-278's prior ddPCR had 6 variant and 1055 reference droplets but did not meet our positive criteria as the $95 \%$ confidence interval overlapped with wild-type samples (Supplemental Methods). The initial ddPCR run for LR16264's had zero variant positive droplets, but subsequent testing from the same DNA isolation sample was unambiguously positive with VAF of $4.8 \%$, possibly reflecting a sample swap during the original screening. These examples highlight difficulties in using tiered screening assays which increase the likelihood of sample swaps, and also demonstrates consideration for repeat 
testing when the diagnostic pre-test probability is high. ${ }^{19}$ We are confident that the pathogenic variant has now been identified for both individuals.

VANseq identified a pathogenic BRAF variant in 3 of the 15 PIK3CA hotspot negative individuals (LR17-322, LR19-346 and LR19-443). All three possessed the same variant (NM_004333.6:c.1799T>A, resulting in p.Val600Glu), which was confirmed by ddPCR in multiple independent tissues, when available (Table 1, Figure 1F-H). Two additional PIK3CA hotspot negative individuals (LR17-319 and LR18-572) possessed 3 or more variant reads supporting the BRAF p.V600E substitution but were not confirmed by ddPCR so were not classified as being BRAF positive (Table S2).

All three individuals with BRAF p.V600E substitutions had macrocystic LM diagnosed at birth (Figure 1). LR17-322 had a large, macrocystic lesion of the posterior neck, de Serres stage 1, that resolved spontaneously over the first few months of life (Figure 1A, B). Surgery was performed at 1 year of age to remove remaining LM and redundant skin. LR19-346's LM was also isolated to the neck, de Serres stage 1 , and was resolving with just observation until an upper respiratory infection induced swelling and the decision was made to remove it surgically (Figure 1C, D). LR19-443 had a large macrocystic LM of the axilla that was treated with sclerotherapy at 1 month of age (Figure 1E). This individual did not have surgery, but cfDNA from aspirated cyst fluid was available for genetic diagnosis. All individuals did well after intervention with no evidence of recurrence and no further procedures or therapy.

Histopathological examination of tissues from two BRAF p.V600E containing LMs showed numerous dilated cystic channels with bland, flattened epithelium that was immunopositive for podoplanin, a marker of lymphatic endothelial cells (Figure 2) ${ }^{20}$ There were no distinguishing histopathological features between BRAF and PIK3CA mutant LMs. The extremely low VAFs of the BRAF p.V600E substitutions (0.3-2\%) indicates that most cells within the malformation do not possess the BRAF substitution. ${ }^{2}$ We hypothesized that BRAF mutant cells would be primarily located within the lymphatic endothelial cells, as has previously been 
medRxiv preprint doi: https://doi.org/10.1101/2021.11.03.21265682; this version posted November 5, 2021. The copyright holder for this preprint (which was not certified by peer review) is the author/funder, who has granted medRxiv a license to display the preprint in perpetuity.

It is made available under a CC-BY-ND 4.0 International license .

shown in PIK3CA positive LMs. ${ }^{21-24}$ To test this we used a BRAF p.V600E specific monoclonal antibody (VE1) ${ }^{25}$. BRAF p.V600E immunostaining was present in cyst-lining endothelial cells in LR17-322 and LR19-346 but not in other cells within the lesion (Figure 2). We detected no BRAF p.V600E staining in two other LM samples bearing p.E545K and p.H1047R PIK3CA substitutions (Figure 2 and data not shown), demonstrating specificity. These results both confirm the presence of the BRAF substitutions within these lesions and demonstrate their localization to lymphatic endothelial cells.

When these results are combined with our previous reports, ${ }^{2 ;} 26$ a more complete picture of allelic and locus heterogeneity within isolated LM appears (Table 2). PIK3CA variants were found in $88 \%$ of the 101 individuals in our cohort, $92 \%$ of which occurred at one of the three PIK3CA hotspots. BRAF p.Val600Glu variants were found in $3 \%$ of individuals with isolated LMa small proportion but a clinically important finding as responses to targeted drug therapies may differ. For example, some BRAF inhibitors produce paradoxical activation of the MAPK pathway and corresponding cellular proliferation in tumors possessing oncogenic mutations in RAS or upstream receptors. ${ }^{27 ;} 28$ The application of VANseq to our cohort of 101 individuals with isolated LM brought our overall diagnostic rate from $\sim 80 \%$ to over $90 \%$, and currently only $9 / 101$ individuals with adequate DNA now remain without a genetic diagnosis. ${ }^{2}$

$B R A F$ is one of the most frequently mutated genes in cancer with a predilection for melanoma, thyroid cancer, colon cancer, and non-small cell lung cancer. p.Val600Glu is the most common oncogenic BRAF substitution, accounting for $>90 \%$ of $B R A F$ mutations. ${ }^{29}$ Nonmosaic constitutional missense and in-frame deletions in $B R A F$ have been reported in rasopathies (e.g. Cardiofaciocutaneous syndrome, Noonan syndrome, and Noonan syndrome with multiple lentigines), ${ }^{30}$ but the p.Val600Glu substitution has never been reported in these diseases. This is likely due to the fact that the BRAF p.Val600Glu substitution is not compatible with embryonic survival except in the mosaic state (i.e,. the Happle hypothesis). ${ }^{31}$ This conclusion is supported by the embryonic lethality seen in constitutional expression of $B R A F$ 
p.Val600Glu in mouse embryos. ${ }^{32}$

Somatic BRAF p.Val600Glu variants have previously been reported to cause arteriovenous malformations (AVMs), though activating mutations in KRAS and MAP2K1 are more common causes. ${ }^{3 ;} 33 ; 34$ The precise mechanisms by which somatic BRAF p.Val600Glu substitutions cause LMs in some cases and AVMs in others likely has to do with the timing and location of the post-zygotic mutation. Additional studies are needed to examine this further. Although activating mutations in oncogenes raise concern for an increased risk of cancer, PIK3CA-related overgrowth syndromes have a low risk ${ }^{17}$ and BRAF p.Val600Glu variants are detected in $>80 \%$ of benign melanocytic nevi, indicating that the single mutation is insufficient to produce melanoma. $^{35}$

All three individuals with BRAF p.Val600Glu substitution in our study had similar clinical phenotypes - large, macrocystic lesions of the neck or body that resolved spontaneously or were treated very early in life. Under the surgical staging system for LMs (de Serres staging), these three individuals would be classified as having stage 1 lesions (unilateral and below the hyoid). ${ }^{36}$ Stage 1 lesions make up only $\sim 31 \%$ of total LM in recent studies, ${ }^{2 ; 36 ; 37}$, suggesting that the BRAF positive LMs may represent a milder LM phenotype than PIK3CA positive LMs. Although our cohort of BRAF positive LMs $(n=3)$ is too small for genotype-phenotype correlations, we speculate that there may be enrichment for BRAF positive LMs among individuals with milder, non-surgical disease, as genetic diagnosis in most LMs to date has required surgically resected tissue. Non-invasive diagnostic methods such as cyst-fluid based cfDNA $^{26}$ may provide a more balanced view of the genetic spectrum among LMs.

Endothelial cells play a key role in the pathogenesis of vascular malformations, and isolation of endothelial cells from these lesions enriches the detection of somatic variants. ${ }^{21-24}$ Prior work in AVM has shown KRAS-mutation specific staining of endothelial cells, ${ }^{38}$ but this not previously been possible for LM as there is no PIK3CA-mutant specific antibody. The presence of $\mathrm{BRAF}^{\mathrm{V} 600 \mathrm{E}}$ staining in lymphatic endothelial cells within the lesions supports the hypothesis 
that cell-non autonomous effects, such as signaling to or recruitment of wild type cells to the lesion, contribute to the formation of LMs. Cell-non autonomous effects have been previously suggested to cause cartilage overgrowth in AVMs, but additional studies will be needed to examine this further. ${ }^{39}$

In conclusion, we demonstrate that a somatic activating pathogenic $B R A F$ variant (c.1799T>A, p.Val600Glu) is present in $3 \%$ of our cohort of individuals with isolated lymphatic malformations. Screening isolated LMs for the three PIK3CA hotspots is an efficient and costeffective approach but will potentially miss clinically important non-hotspot PIK3CA and BRAF variation. Our use of VANseq, a high-depth, full gene sequencing panel, increased the positivity rate for our cohort of LM from $\sim 80$ to $>90 \%$. Additionally, our results suggest the need for studies to examine the efficacy of BRAF inhibition in the treatment of lymphatic malformations. 


\section{Supplemental Data}

Supplemental data include Supplemental Methods and Tables S1 and S2.

\section{Acknowledgements}

We thank the participants and their families. This study was funded by the US National Institutes of Health under National Heart, Lung, and Blood Institute (NHLBI) grants F32HL147398 (to K.Z.) and R01 HL130996 (to JTB), as well as a Burroughs Wellcome Career Award for Medical Scientists 1014700 (to JTB), and a Seattle Children's Hospital Guild Association Funding Focus Award (to JP). We also acknowledge the Seattle Children's Vascular Anomalies Program and especially the interventional radiology team for their support in sample collection, as well as Dr. Raj Kapur for his assistance with pathology. The content of this work is solely the responsibility of the authors and does not necessarily represent the official views of the funding sources.

\section{Declaration of Interests}

R. A. Bly: Co-founder EigenHealth, Inc, Consultant to SpiWay, LLC. Dr. Randall Bly holds a financial interest of ownership equity with Wavely Diagnostics, Inc.

The remaining authors have declared that no conflict of interest exists.

\section{Web Resources}

\section{https://cancer.sanger.ac.uk/cosmic}

\section{https://seattlechildrenslab.testcatalog.org/show/LAB1920-1}


Figure titles and legends

Figure 1. Clinical features of BRAF-mutated LM and confirmation of genetic diagnosis. Clinical photos of LR17-322 (A) and LR19-346 (C) showing posterior neck LM. Corresponding CT (LR17-322, B) and MRI (LR19-346, D, and LR19-443, E) images demonstrate macrocystic lesions with minimal septations of the posterior lateral neck and axilla. Integrated Genomics Viewer image for LR19-346 demonstrating somatic BRAF p.Val600Glu variant (F), confirmed on droplet digital PCR (G). Variant concentration image from Quantasoft shows variability in mutation prevalence between samples $(\mathrm{H}) .{ }^{*}$ Note: Images $A$ and $B$ previously published prior to identification of patient's genetic variant. ${ }^{40}$

\section{Figure 2. Histology and immunohistochemistry of PIK3CA and BRAF mutated LM.}

Lymphatic malformation tissue from two individuals with BRAF p.Val600Glu mutation (A-F) and one individual with PIK3CA p.H1047R mutation (G-I). H\&E stain (panels A,D,G) show dilated cystic channels with bland, flattened epithelium. Panels $\mathrm{B}, \mathrm{E}$, and $\mathrm{H}$ show presence of podoplanin (aka D2-40) immunoreactivity in endothelial cells. Panels on the right shows BRAF p.V600E immunoreactivity (VE1 staining) in endothelial cells in BRAF mutant lymphatic malformation (panels C, F) but not in PIK3CA mutant lymphatic malformation (panel I). 
Table 1. Somatic variants in LM detected by VANseq and confirmed by ddPCR.

\begin{tabular}{|c|c|c|c|c|c|c|c|c|}
\hline \multirow[b]{2}{*}{ Subject } & \multirow[b]{2}{*}{$\mathrm{Age}^{\mathrm{a}}$} & \multirow[b]{2}{*}{ Sex } & \multirow[b]{2}{*}{$\begin{array}{l}\text { Location, } \\
\text { stage }^{\mathrm{b}}\end{array}$} & \multirow[b]{2}{*}{ Variant } & \multirow[b]{2}{*}{ Sample } & \multicolumn{2}{|c|}{ VANseq } & \multirow{2}{*}{$\begin{array}{c}\mathrm{ddPCR} \\
\mathrm{VAF}^{\mathrm{d}} \\
(\%)\end{array}$} \\
\hline & & & & & & $\begin{array}{l}\text { VAF } \\
(\%)\end{array}$ & $\begin{array}{c}\text { Var/WT } \\
\text { reads }\end{array}$ & \\
\hline \multirow{9}{*}{ LR18-536 } & \multirow{9}{*}{$1-2 y$} & \multirow{9}{*}{$\mathrm{F}$} & \multirow{9}{*}{$\begin{array}{l}\text { Neck and } \\
\text { parotid, III }\end{array}$} & \multirow{9}{*}{$\begin{array}{c}\text { PIK3CA } \\
\text { p.N345K }\end{array}$} & Lesion $\mathrm{A}$ & 1.3 & $21 / 1669$ & 1.1 \\
\hline & & & & & Lesion B & - & - & 0.2 \\
\hline & & & & & Lesion C & - & - & NEG \\
\hline & & & & & Lesion D & - & - & 0.2 \\
\hline & & & & & Lesion $\mathrm{E}$ & - & - & 1.4 \\
\hline & & & & & Lesion $\mathrm{F}$ & - & - & 0.5 \\
\hline & & & & & Lesion G & - & - & 0.9 \\
\hline & & & & & Skin & - & - & 0.3 \\
\hline & & & & & Salivary gland & - & - & NEG \\
\hline \multirow[t]{2}{*}{ LR16-278 } & $1-2 y$ & $\mathrm{~F}$ & Neck, I & PIK3CA & Lesion & 0.7 & $12 / 1709$ & 0.5 \\
\hline & & & & p.E545K & & & & \\
\hline \multirow[t]{2}{*}{ LR16-264 } & $3-4 y$ & $\mathrm{~F}$ & Neck, I & PIK3CA & Lesion & 11.9 & $7 / 59 * *$ & 4.8 \\
\hline & & & & p.E545K & & & & \\
\hline \multirow[t]{2}{*}{ LR17-322 } & $9-12 m$ & $M$ & Neck, I & $B R A F$ & Lesion & 2.1 & $34 / 1618$ & 1.7 \\
\hline & & & & p.V600E & Skin & - & - & NEG \\
\hline \multirow{7}{*}{ LR19-346 } & \multirow{7}{*}{$4-6 m$} & \multirow{7}{*}{$\mathrm{F}$} & \multirow{7}{*}{ Neck, I } & \multirow{7}{*}{$\begin{array}{c}\text { BRAF } \\
\text { p.V600E }\end{array}$} & Lesion, deep & 0.6 & $7 / 1150$ & 1.2 \\
\hline & & & & & Lesion, inferior & - & - & 0.9 \\
\hline & & & & & Lesion, superior & - & - & NEG \\
\hline & & & & & Lesion, no location & - & - & 3.6 \\
\hline & & & & & Skin & - & - & NEG \\
\hline & & & & & Fat & - & - & NEG \\
\hline & & & & & Muscle & - & - & NEG \\
\hline \multirow{4}{*}{ LR19-443 } & \multirow{4}{*}{$0-3 \mathrm{~m}$} & \multirow{4}{*}{$M$} & \multirow{4}{*}{ Axilla, NS } & & Cyst fluid, $A^{c}$ & - & - & 0.2 \\
\hline & & & & $B R A F$ & Cyst fluid, $B^{c}$ & 0.3 & $4 / 1462$ & 0.1 \\
\hline & & & & p.V600E & Cyst fluid, $\mathrm{C}^{\mathrm{c}}$ & - & - & 0.3 \\
\hline & & & & & Cyst fluid pellet & - & - & NEG \\
\hline
\end{tabular}

Abbreviations: ddPCR - droplet digital polymerase chain reaction, NEG - no variant detected, NS - not staged, VAF - variant allele fraction, Var - variant, WT - wild-type, ${ }^{* *}$ lower than typical droplet count

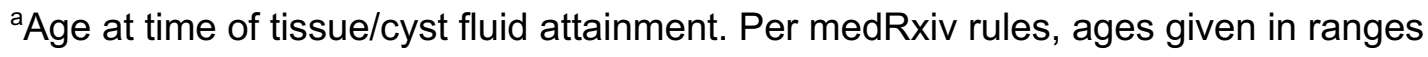
${ }^{b}$ de Serres stage ${ }^{36}$

${ }^{\mathrm{c} C e l l-f r e e ~ D N A ~ w a s ~ a s s a y e d ~ f r o m ~ c y s t ~ f l u i d ~ s a m p l e s . ~}$ 
medRxiv preprint doi: https://doi.org/10.1101/2021.11.03.21265682; this version posted November 5, 2021. The copyright holder for this preprint (which was not certified by peer review) is the author/funder, who has granted medRxiv a license to display the preprint in perpetuity. It is made available under a CC-BY-ND 4.0 International license.

${ }^{d} d d P C R$ VAF calculated using droplet concentrations and only reported for samples in which sample variant concentration was statistically different from WT control variant concentration based on $95 \%$ total error confidence intervals. 
Table 2. The genetic spectrum of LM including BRAF p.V600E

\begin{tabular}{|c|c|c|c|c|c|c|c|}
\hline & \multicolumn{5}{|c|}{ PIK3CA } & \multirow{2}{*}{$\begin{array}{c}\text { BRAF } \\
\text { V600E }\end{array}$} & \multirow[b]{2}{*}{$N E G^{a}$} \\
\hline & $\mathrm{H} 1047 \mathrm{R}$ & E545K & E542K & Other & Total & & \\
\hline Zenner et al. 2019 & 22 & 18 & 18 & 6 & 64 & - & - \\
\hline Zenner et al. 2020 & 7 & 9 & 5 & 0 & 21 & - & - \\
\hline Current study & 1 & 2 & 0 & 1 & 4 & 3 & 9 \\
\hline Total, $\mathrm{N}=101^{\mathrm{b}}$ & 30 & 29 & 23 & 7 & 89 (88.1\%) & $3(3.0 \%)$ & 9 (8.9\%) \\
\hline
\end{tabular}

Abbreviations: NEG - no variant detected.

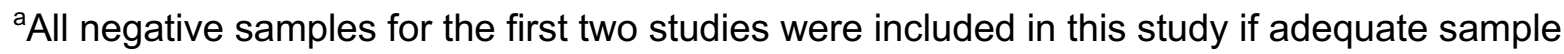
was available for VANseq testing.

${ }^{\text {b}}$ Total includes only individuals with detected mutations or sufficient DNA to undergo VANseq testing. 


\section{References}

1. Luks, V.L., Kamitaki, N., Vivero, M.P., Uller, W., Rab, R., Bovee, J.V., Rialon, K.L., Guevara, C.J., Alomari, A.I., Greene, A.K., et al. (2015). Lymphatic and other vascular malformative/overgrowth disorders are caused by somatic mutations in PIK3CA. J Pediatr 166, 1048-1054.e1041-1045.

2. Zenner, K., Cheng, C.V., Jensen, D.M., Timms, A.E., Shivaram, G., Bly, R., Ganti, S., Whitlock, K.B., Dobyns, W.B., Perkins, J., et al. (2019). Genotype correlates with clinical severity in PIK3CA-associated lymphatic malformations. JCI Insight.

3. Al-Olabi, L., Polubothu, S., Dowsett, K., Andrews, K.A., Stadnik, P., Joseph, A.P., Knox, R., Pittman, A., Clark, G., Baird, W., et al. (2018). Mosaic RAS/MAPK variants cause sporadic vascular malformations which respond to targeted therapy. J Clin Invest 128, 1496-1508.

4. Padia, R., Bly, R., Bull, C., Geddis, A.E., and Perkins, J. (2018). Medical Management of Vascular Anomalies. Curr Treat Options Pediatr 4, 221-236.

5. Adams, D.M., Trenor, C.C., 3rd, Hammill, A.M., Vinks, A.A., Patel, M.N., Chaudry, G., Wentzel, M.S., Mobberley-Schuman, P.S., Campbell, L.M., Brookbank, C., et al. (2016). Efficacy and Safety of Sirolimus in the Treatment of Complicated Vascular Anomalies. Pediatrics 137, e20153257.

6. Edwards, E.A., Phelps, A.S., Cooke, D., Frieden, I.J., Zapala, M.A., Fullerton, H.J., and Shimano, K.A. (2020). Monitoring Arteriovenous Malformation Response to GenotypeTargeted Therapy. Pediatrics 146.

7. Hammer, J., Seront, E., Duez, S., Dupont, S., Van Damme, A., Schmitz, S., Hoyoux, C., Chopinet, C., Clapuyt, P., Hammer, F., et al. (2018). Sirolimus is efficacious in treatment for extensive and/or complex slow-flow vascular malformations: a monocentric prospective phase II study. Orphanet J Rare Dis 13, 191. 
8. Lekwuttikarn, R., Lim, Y.H., Admani, S., Choate, K.A., and Teng, J.M.C. (2019). GenotypeGuided Medical Treatment of an Arteriovenous Malformation in a Child. JAMA Dermatology 155, 256-257.

9. Parker, V.E.R., Keppler-Noreuil, K.M., Faivre, L., Luu, M., Oden, N.L., De Silva, L., Sapp, J.C., Andrews, K., Bardou, M., Chen, K.Y., et al. (2019). Safety and efficacy of low-dose sirolimus in the PIK3CA-related overgrowth spectrum. Genet Med 21, 1189-1198.

10. Triana, P., Dore, M., Cerezo, V.N., Cervantes, M., Sanchez, A.V., Ferrero, M.M., Gonzalez, M.D., and Lopez-Gutierrez, J.C. (2017). Sirolimus in the Treatment of Vascular Anomalies. Eur J Pediatr Surg 27, 86-90.

11. Venot, Q., Blanc, T., Rabia, S.H., Berteloot, L., Ladraa, S., Duong, J.P., Blanc, E., Johnson, S.C., Hoguin, C., Boccara, O., et al. (2018). Targeted therapy in patients with PIK3CArelated overgrowth syndrome. Nature 558, 540-546.

12. Brouillard, P., Schlogel, M.J., Homayun Sepehr, N., Helaers, R., Queisser, A., Fastre, E., Boutry, S., Schmitz, S., Clapuyt, P., Hammer, F., et al. (2021). Non-hotspot PIK3CA mutations are more frequent in CLOVES than in common or combined lymphatic malformations. Orphanet J Rare Dis 16, 267.

13. Fruman, D.A., Chiu, H., Hopkins, B.D., Bagrodia, S., Cantley, L.C., and Abraham, R.T. (2017). The PI3K Pathway in Human Disease. Cell 170, 605-635.

14. Dogruluk, T., Tsang, Y.H., Espitia, M., Chen, F., Chen, T., Chong, Z., Appadurai, V., Dogruluk, A., Eterovic, A.K., Bonnen, P.E., et al. (2015). Identification of Variant-Specific Functions of PIK3CA by Rapid Phenotyping of Rare Mutations. Cancer Res 75, 53415354.

15. Gymnopoulos, M., Elsliger, M.A., and Vogt, P.K. (2007). Rare cancer-specific mutations in PIK3CA show gain of function. Proc Natl Acad Sci U S A 104, 5569-5574. 
16. Lek, M., Karczewski, K.J., Minikel, E.V., Samocha, K.E., Banks, E., Fennell, T., O'DonnellLuria, A.H., Ware, J.S., Hill, A.J., Cummings, B.B., et al. (2016). Analysis of proteincoding genetic variation in 60,706 humans. Nature 536, 285-291.

17. Gripp, K.W., Baker, L., Kandula, V., Conard, K., Scavina, M., Napoli, J.A., Griffin, G.C., Thacker, M., Knox, R.G., Clark, G.R., et al. (2016). Nephroblastomatosis or Wilms tumor in a fourth patient with a somatic PIK3CA mutation. Am J Med Genet A 170, 2559-2569.

18. Richards, S., Aziz, N., Bale, S., Bick, D., Das, S., Gastier-Foster, J., Grody, W.W., Hegde, M., Lyon, E., Spector, E., et al. (2015). Standards and guidelines for the interpretation of sequence variants: a joint consensus recommendation of the American College of Medical Genetics and Genomics and the Association for Molecular Pathology. Genet Med 17, 405-424.

19. Akobeng, A.K. (2007). Understanding diagnostic tests 2: likelihood ratios, pre- and post-test probabilities and their use in clinical practice. Acta Paediatr 96, 487-491.

20. Fukunaga, M. (2005). Expression of D2-40 in lymphatic endothelium of normal tissues and in vascular tumours. Histopathology 46, 396-402.

21. Blesinger, H., Kaulfus, S., Aung, T., Schwoch, S., Prantl, L., Rosler, J., Wilting, J., and Becker, J. (2018). PIK3CA mutations are specifically localized to lymphatic endothelial cells of lymphatic malformations. PLoS ONE 13, e0200343.

22. Boscolo, E., Coma, S., Luks, V.L., Greene, A.K., Klagsbrun, M., Warman, M.L., and Bischoff, J. (2015). AKT hyper-phosphorylation associated with PI3K mutations in lymphatic endothelial cells from a patient with lymphatic malformation. Angiogenesis 18, $151-162$.

23. Glaser, K., Dickie, P., Neilson, D., Osborn, A., and Dickie, B.H. (2018). Linkage of Metabolic Defects to Activated PIK3CA Alleles in Endothelial Cells Derived from Lymphatic Malformation. Lymphat 16, 43-55. 
24. Osborn, A.J., Dickie, P., Neilson, D.E., Glaser, K., Lynch, K.A., Gupta, A., and Dickie, B.H. (2015). Activating PIK3CA alleles and lymphangiogenic phenotype of lymphatic endothelial cells isolated from lymphatic malformations. Hum Mol Genet 24, 926-938.

25. Ritterhouse, L.L., and Barletta, J.A. (2015). BRAF V600E mutation-specific antibody: A review. Semin Diagn Pathol 32, 400-408.

26. Zenner, K., Jensen, D.M., Cook, T.T., Dmyterko, V., Bly, R.A., Ganti, S., Mirzaa, G.M., Dobyns, W.B., Perkins, J.A., and Bennett, J.T. (2021). Cell-free DNA as a diagnostic analyte for molecular diagnosis of vascular malformations. Genet Med 23, 123-130.

27. Cichowski, K., and Janne, P.A. (2010). Drug discovery: inhibitors that activate. Nature 464, 358-359.

28. Hatzivassiliou, G., Song, K., Yen, I., Brandhuber, B.J., Anderson, D.J., Alvarado, R., Ludlam, M.J., Stokoe, D., Gloor, S.L., Vigers, G., et al. (2010). RAF inhibitors prime wildtype RAF to activate the MAPK pathway and enhance growth. Nature 464, 431-435.

29. Forbes, S.A., Beare, D., Boutselakis, H., Bamford, S., Bindal, N., Tate, J., Cole, C.G., Ward, S., Dawson, E., Ponting, L., et al. (2017). COSMIC: somatic cancer genetics at highresolution. Nucleic Acids Res 45, D777-D783.

30. Sarkozy, A., Carta, C., Moretti, S., Zampino, G., Digilio, M.C., Pantaleoni, F., Scioletti, A.P., Esposito, G., Cordeddu, V., Lepri, F., et al. (2009). Germline BRAF mutations in Noonan, LEOPARD, and cardiofaciocutaneous syndromes: molecular diversity and associated phenotypic spectrum. Hum Mutat 30, 695-702.

31. Happle, R. (1987). Lethal genes surviving by mosaicism: a possible explanation for sporadic birth defects involving the skin. J Am Acad Dermatol 16, 899-906.

32. Mercer, K., Giblett, S., Green, S., Lloyd, D., DaRocha Dias, S., Plumb, M., Marais, R., and Pritchard, C. (2005). Expression of endogenous oncogenic V600EB-raf induces proliferation and developmental defects in mice and transformation of primary fibroblasts. Cancer Res 65, 11493-11500. 
33. Goss, J.A., Huang, A.Y., Smith, E., Konczyk, D.J., Smits, P.J., Sudduth, C.L., Stapleton, C., Patel, A., Alexandrescu, S., Warman, M.L., et al. (2019). Somatic mutations in intracranial arteriovenous malformations. PLoS ONE 14, e0226852.

34. Hong, T., Yan, Y., Li, J., Radovanovic, I., Ma, X., Shao, Y.W., Yu, J., Ma, Y., Zhang, P., Ling, F., et al. (2019). High prevalence of KRAS/BRAF somatic mutations in brain and spinal cord arteriovenous malformations. Brain 142, 23-34.

35. Pollock, P.M., Harper, U.L., Hansen, K.S., Yudt, L.M., Stark, M., Robbins, C.M., Moses, T.Y., Hostetter, G., Wagner, U., Kakareka, J., et al. (2003). High frequency of BRAF mutations in nevi. Nat Genet 33, 19-20.

36. de Serres, L.M., Sie, K.C., and Richardson, M.A. (1995). Lymphatic malformations of the head and neck. A proposal for staging. Arch Otolaryngol Head Neck Surg 121, 577-582.

37. Bonilla-Velez, J., Whitlock, K.B., Ganti, S., Zenner, K., Cheng, C.V., Jensen, D.M., Pham, M.M., Mitchell, R.M., Dobyns, W., Bly, R.A., et al. (2021). Acetylsalicylic acid suppression of the PI3K pathway as a novel medical therapy for head and neck lymphatic malformations. Int J Pediatr Otorhinolaryngol 151, 110869.

38. Oka, M., Kushamae, M., Aoki, T., Yamaguchi, T., Kitazato, K., Abekura, Y., Kawamata, T., Mizutani, T., Miyamoto, S., and Takagi, Y. (2019). KRAS G12D or G12V Mutation in Human Brain Arteriovenous Malformations. World Neurosurg 126, e1365-e1373.

39. Konczyk, D.J., Goss, J.A., Smits, P.J., Sudduth, C.L., Al-Ibraheemi, A., and Greene, A.K. (2020). Arteriovenous Malformation MAP2K1 Mutation Causes Local Cartilage Overgrowth by a Cell-Non Autonomous Mechanism. Sci Rep 10, 4428.

40. Perkins, J.A., Maniglia, C., Magit, A., Sidhu, M., Manning, S.C., and Chen, E.Y. (2008). Clinical and radiographic findings in children with spontaneous lymphatic malformation regression. Otolaryngol Head Neck Surg 138, 772-777. 
medRxiv preprint doi: https://doi.org/10.1101/2021.11.03.21265682; this version posted November 5, 2021. The copyright holder for this preprint (which was not certified by peer review) is the author/funder, who has granted medRxiv a license to display the preprint in perpetuity.

It is made available under a CC-BY-ND 4.0 International license.

\section{Figure 1}

\section{Images $A$ and $C$ removed per medRxiv policy}
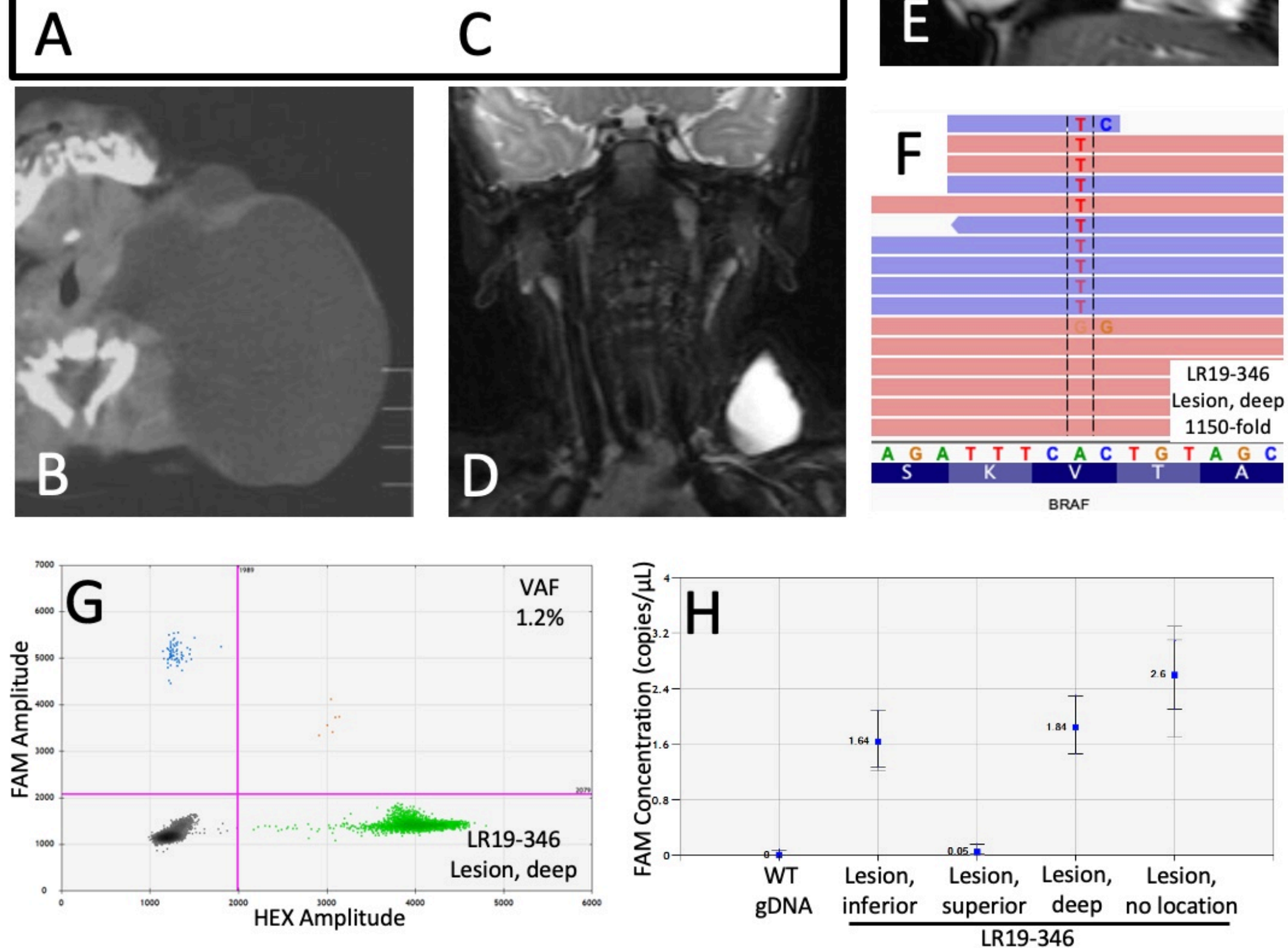
medRxiv preprint doi: https://doi.org/10.1101/2021.11.03.21265682; this version posted November 5, 2021. The copyright holder for this preprint (which was not certified by peer review) is the author/funder, who has granted medRxiv a license to display the preprint in perpetuity.

It is made available under a CC-BY-ND 4.0 International license .

Figure 2

$H \& E$

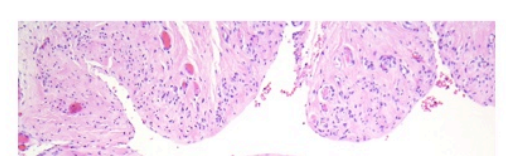

LR17-322

$2 \% \mathrm{VAF}$

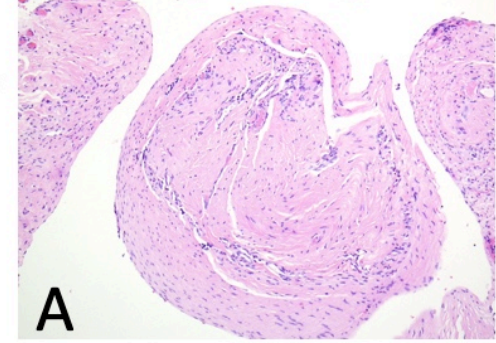

$B R A F^{\mathrm{V} 600 \mathrm{E}} \mathrm{LM}$

PIK3CA ${ }^{H 1047 R}$ LM

LR19-346

D

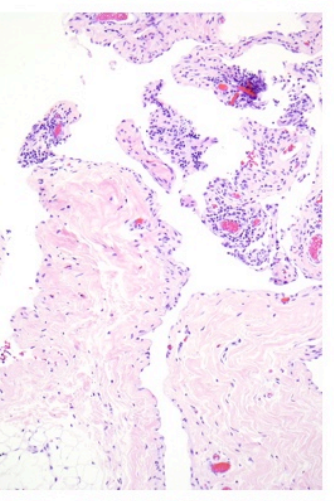

$3 \%$ VAF

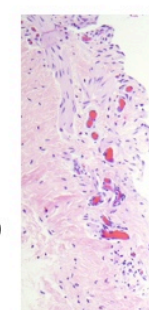

E

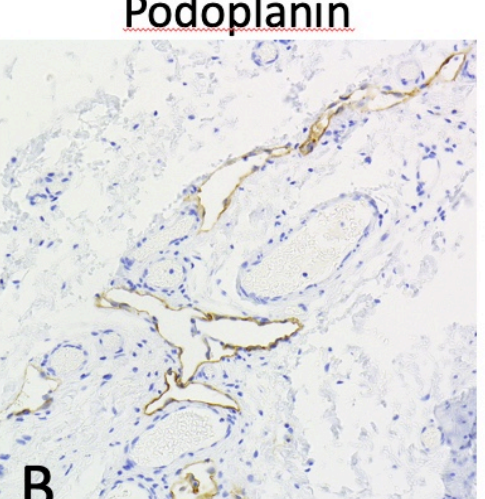

C

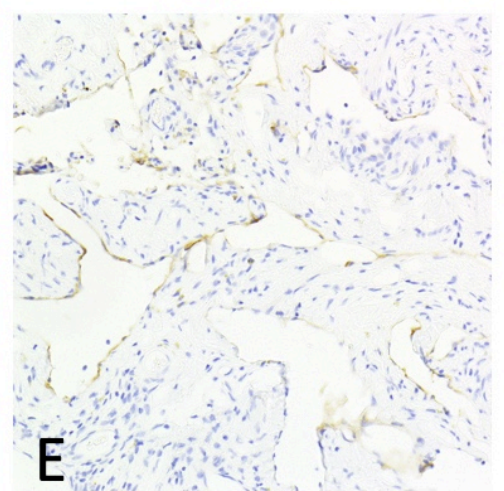

F
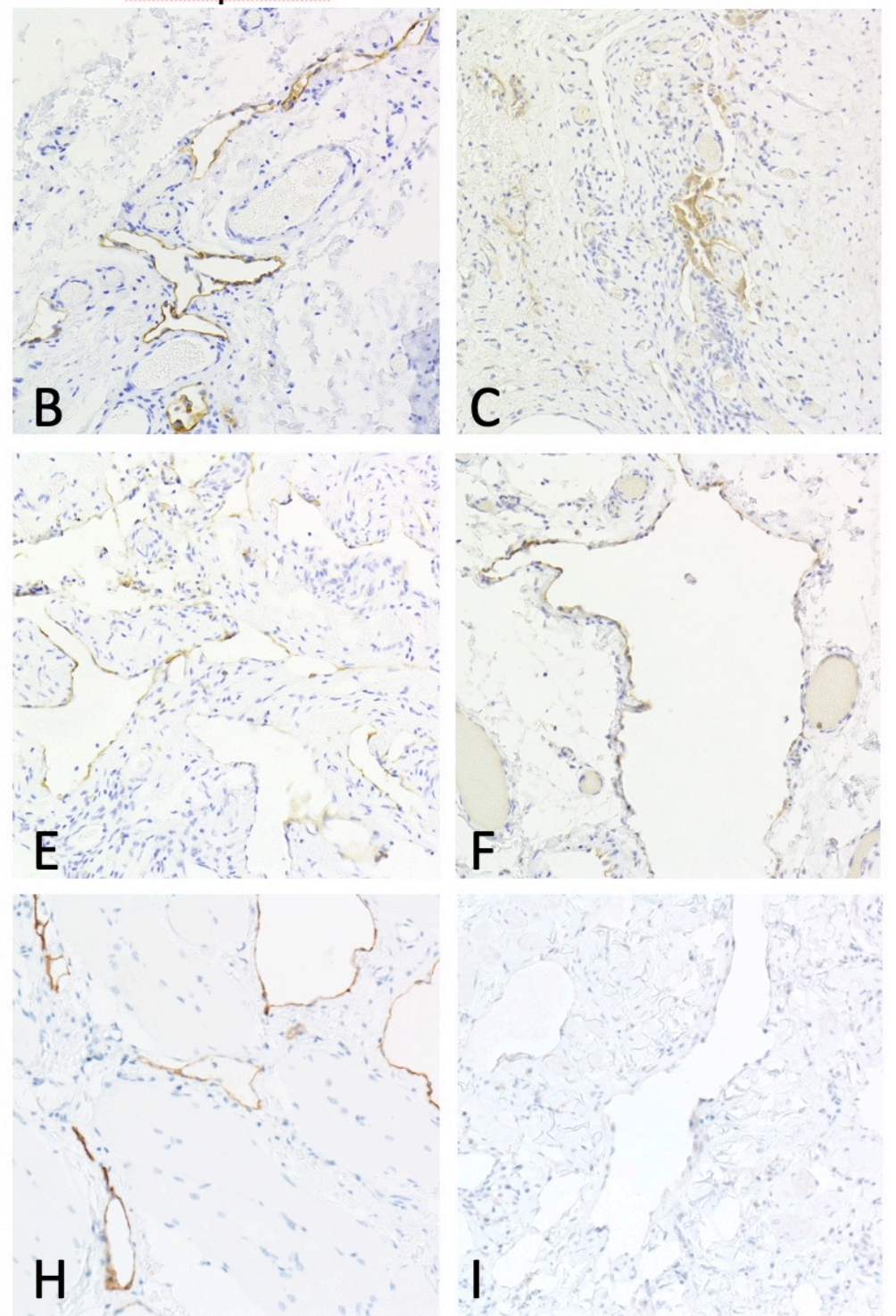

BRAF $^{\text {V600E }}$
G

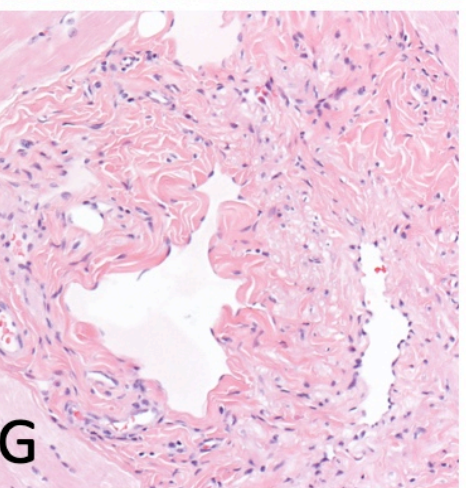

